\title{
Nyttige bøger er teknologi \\ - fra polyteknisk litteratur til teknisk prosa
}

af Michael F. Wagner

\section{Hele verden på udstilling}

På Verdensudstillingen i London i 1851 betjente industrialismen sig af nye offentlighedsformer til at proklamere sine fremskridt. Ideen, at man skulle sætte alverdens kunst, håndværk og industri på udstilling, var forud blevet hånet og latterliggjort. Da "Den store Udstilling" endelig åbnede i Hyde Park den 1. maj efter megen skærmydsel, vendte stemningen og nu ville mediernes begejstring overhovedet ingen ende tage. Siden da har offentligheden stort set fascineret dyrket det teknologiske fremskridt i både ord og gerning.

Den monstrøse udstillingsbygning, som Punch kærligt døbte "The Chrystal Palace", var tænkt og udført som en teknologisk manifestation af det moderne fremskridt. Bygningen er siden søgt overgået på andre verdensudstillinger. Nye og helt utraditionelle byggematerialer sat sammen med den dristigste arkitektur, sikrede bygningen - og dermed også resten af udstillingen - opmærksomhed fra alverdens moderne indstillede mennesker. Krystalpaladset blev et symbol på fremskridtet.

Eiffeltårnet, opført til Verdensudstillingen i Paris i 1887, står endnu i dag som et symbol på det frembrusende tekniske fremskridt i det 19 . århundrede. Udsigtstårnet par exellence, dette komplet unyttige panoptikon, modernitetens højeste triumf, demonstrerer teknologiens ypperste funktion i samfundet: at vise sig selv frem for offentligheden. Projektet symboliserer fremskridtet med sine 300 meter, der først blev overgået med Chrysler-bygningen i 1930. Den teknologiske iscenesættelse af teknologien er blevet et vigtigt vidnesbyrd om fremskridtet i sig selv. 
Det gælder for Eiffel's konstruerede tårn, som det gælder for al ny teknologi fra Samuel Colt's "Peacemaker" over månerejser til PC'ere og gensplejsning, at den skal præsentere sig på en sympatisk formel, formidles og bringes til offentlighedens kendskab for at være et fremskridt. Før som nu er det i højeste grad et spørgsmål om at få symbolerne fortolket og sat på tryk, så de kan appellere til fantasien. Uden iscenesættelsen har den brede offentlighed nemlig ikke store muligheder for at stifte bekendtskab med nye teknologiske fænomener.

Derfor er selve repræsentationen af teknologien, der sker med tekniske artefakter, i billede, lyd og tekst, blevet det væsentlige moment for forståelsen af teknik som et samfundsskabt fænomen. Forklaringen kommer først i form af teksten og fortællingen om teknologien. Uden besyngelsen af fremskridtet ville den tekniske udvikling ikke virke overbevisende. Teknikken kræver en iscenesættelse for at kunne blive forstået i sin rette betydningsfulde rolle i samfundet. I sig selv meddeler teknikken intet, den fungerer blot efter beskrivelsen. Derfor er det fremskridtets herolder, ikke mindst forfatterne, der skaber det erkendelsesmæssige grundlag for at forstå teknikkens betydning.

\section{Oplysningstiden savnede en teknologi}

Teknologien præsenterer sig først med den nyttige tekst, der fortæller om teknikkens revolution i samfundet. Skønt der findes nedskrevne tekniske vejledninger og beskrivelser af landbruget og håndværket langt tilbage i historien, er teknologien sådan set en moderne historisk konstruktion. Som eksempel på præ-moderne teknologier kan nævnes de romerske landbrugsforfattere i antikken, arkitekten Villard de Honnecourt's optegnelser fra middelalderen, eller Agricola's De re Metallica fra 1556, hvor minedriftens teknik blev systematisk beskrevet og illustreret med træsnit.

Polyteknikken, den revolutionerende tanke, at man systematisk skulle indsamle viden om alle håndværk, beskrive teknik og redskaber på en overskuelig og pædagogisk facon for at skabe fremskridt, opstår først med Oplysningstiden. Den polytekniske ambition om at ville afhandle alle former for teknik, stammer fra den store franske Encyclopædi, hvor redaktøren, Denis Diderot, systematisk forsøgte at indsamle viden om og beskrive 
alverdens håndværk og teknik. Til gengæld savnede Encyclopædien endnu den didaktiske dimension. Den var pædagogisk anskueliggørende, men fungerede ikke som brugsanvisning eller en teknologi i moderne forstand. Man kunne næppe lære at gøre tingene efter Diderots anvisninger, det ville kræve en langt højere grad af teknisk specialisering. Karakteristisk nok manglede Encyclopædien da også opslaget 'Teknologi', for begrebet var endnu ikke blevet opfundet som en videnskab.

Herhjemme kom en samtidig forløber til den teknologiske specialisering, da lærer ved Sorø Akademi, Jens Kraft, udgav sine Forelæsninger over Mekanik i to bind i 1763-64. Denne udgivelse kom ikke til at grundlægge en videnskabelig teknologi i betydningen matematisk bevægelseslære og teknik. Det var den encyclopædiske tradition for at beskrive al teknik grundigt, fuldstændigt og med almen nytte for øje, som blev den fremherskende metode i polyteknikken fra slutningen af det 18. århundrede. Den matematiske metode at beregne tingene i deres enkelte dele bliver først fremherskende et århundrede senere. I den litterære offentlighed fremkom efter Jens Kraft udelukkende teknologier, der byggede på den systematiske indsamling og udstilling af teknisk viden $\mathrm{i}$ form af beskrivelser af håndværkets teknikker.

\section{Anledning til teknologi}

I 1798 oversatte Andreas Svendsen en 18 år gammel tysk lærebog med titlen Anledning til Technologie, som udkom på Soldins Forlag i København. Det var en systematisk baseret polyteknik, som på videnskabelig manér bestræbte sig på at afhandle de eksisterende håndværk og kunster ved at beskrive redskaber, materialer, fremgangsmåder og økonomi. Forfatteren til afhandlingen, Johann Beckmann, var professor i økonomi ved universitetet i Göttingen. Her underviste han kommende embedsmænd i datidens statslige forvaltningslære, den såkaldte kameral-videnskab. Professor Beckmanns polytekniske værk handlede om håndværkets betydning for statshusholdningen. Det er første gang termen teknologi benyttes om et videnskabelige værk.

Kameralvidenskaben opfandt altså begrebet om teknologien og grundlagde samtidig en videnskabelig teknologisk tradition, der kom i 
rivende udvikling i første halvdel af det 19. århundrede. Opskrifter, recepter, fremgangsmåder og teknikker blev beskrevet og forklaret efter bedste evne som grundlaget for samfundshusholdningen. Ligesom teknologibegrebet i sig selv var en sproglig nydannelse, fandtes der ingen begreber, som kortfattet kunne karakterisere forskellige konkrete tekniske fænomener. Ved overførelsen af den ny teknologi til Danmark 18 år senere stødte Andreas Svendsen ind i denne objektive erkendelsesmæssige skranke. Som oversætter savnede han simpelthen ord for mange af de afhandlede materier. I 'Oversætterens Fortale' diskuterer han sin fremgangsmåde overfor dette problem, som danske håndværkere ikke havde kunnet bidrage til at løse, fordi de ikke havde nogen teknologi i ordets forstand:

"Jeg indsaae forud, at det vilde blive vanskeligt Arbeide at oversætte Professor Beckmans Technologie. Uagtet den Hielp, man kan have af de udførlige Beskrivelser og Tegninger, der i Frankrige og Tydskland ere udgivne om enhver Kunst, og uagtet man dog vel altid kunde vente nogen Oplysning hos en Kunstner, Haandværksmand ec. i enhvers Fag, frygtede jeg, at der vilde blive uundgaaelige Mangler ... Jeg erfarede siden ved mange Leiligheder, at mange simple Ting, endog indtil Redskabers navne, ansees for Vigtigheder, eller Ting, hvorom man ikke maa spørge, og at Svarene enten bleve utilstrækkelige eller forvirrende ... Jeg beder derfor, at eet og andet Ord, som jeg undertiden har brugt, ikke maa betragtes som et egenmægtigt Kunstord eller en Ligegyldighed mod Sproget, men som Nødhjelp for at spare Rummet."

Begreberne fandtes altså ikke på dansk i forvejen, det var nu nødvendigt at opfindedem, hvis beskrivelsen ikkeskulle sprænge alle rammer. Teknologien måtte udstyres med et sprog for at kunne virke.

De nyttige oplysningsskrifter eller teknologier florerede ligegodt i sidste fjerdedel af det 18. århundrede. Ofte var de begrænset til en enkelt materie som farveriets kunst, om hvilken der udkom mindst 21 afhandlinger mellem 1768 og 1830. Af titlen fremgik ofte, at recepten var forklaret for Fruentimmere. Kunsten at brænde brændevin blev også særdeles grundigt afhandlet. På dansk udkom der ikke mindre end 24 afhandlinger om brænderikunsten mellem 1789 og 1830. Men overvejende var det landbrugstekniske spørgsmål, som blev afhandlet i denne periode. Landhusholdningsselskabets 
skrifter bærer vidnesbyrd herom, ligesom et Magasin for Næringsstanden blev udgivet af D. Didrichsen fra 1795 på Soldins Forlag.

\section{Et Magazin for Kunstnere og Haandværkere}

Det er først med Napoleon-krigenes afslutning, at informationerne om ny teknologi for alvor begyndte at strømme gennem Europa. Nu var ny teknologi ikke længere anset for en farlig og hemmelig viden, der skulle beskyttes for enhver pris, men blev forvandlet til nyttig viden, som skulle formidles og distribueres i videst muligt omfang. Den teknologiske nyhedsstrøm fandt hurtigt et gangbart medie i skikkelse af det polytekniske tidsskrift, der udkom hver uge med præsentation af ny teknik og referater fra de seneste begivenheder i udviklingen. Kemiker og fabrikant Johann Gottfried Dingler udgav Polytechnisches Journal i Stuttgart fra 1820. Dette ugeskrift dannede snart forbillede for lignende udgivelser.

Herhjemme indledte en ung nybagt professor i matematik ved Kunstakademiet, Georg Frederik Ursin, et omfattende polyteknisk forfatterskab med at udgive et tidsskrift Magazin for Kunstnere og Haandværkere. Det udkom fra den 4 . september 1826 og frem til 1842 i tre rækker med et toårigt ophold i midten af trediverne. Magazinet er et bemærkelsesværdigt vidnesbyrd om udviklingen af ny teknologi i første halvdel af det 19. århundrede. Hver årgang indeholdt omkring 500 sider tekst og illustrationer i form af tegninger og tekniske diagrammer. Stoffet kan inddeles i tre kategorier. Den mindste kategori omfatter originalt meddelt stof i form af beretninger, recepter og opskrifter fra læserskaren. Hertil kommer en kategori af redaktionelt stof, som regel i form af reportager, bekendtgørelser og kommentarer. Langt den største kategori omfatter referater af udenlandske meddelelser, som er hentet fra tilsvarende tidsskrifter, afhandlinger, leksika og aviser i Tyskland, Frankrig og England; altså det man i dag kunne kalde for teknologioverførsel.

Hastigheden af informationsstrømmen i Ursins Magazin kan illustreres med omtalen af "Den store mekaniske Væddekjørsel mellem Liverpol og Manchester i oktober 1829", som fremkom en måned efter begivenheden fandt sted. Reportagen byggede på oversættelse af de tre foregående udgaver af Londons Mechanic's Magazine, og bringer såvel beskrivelser af hele 


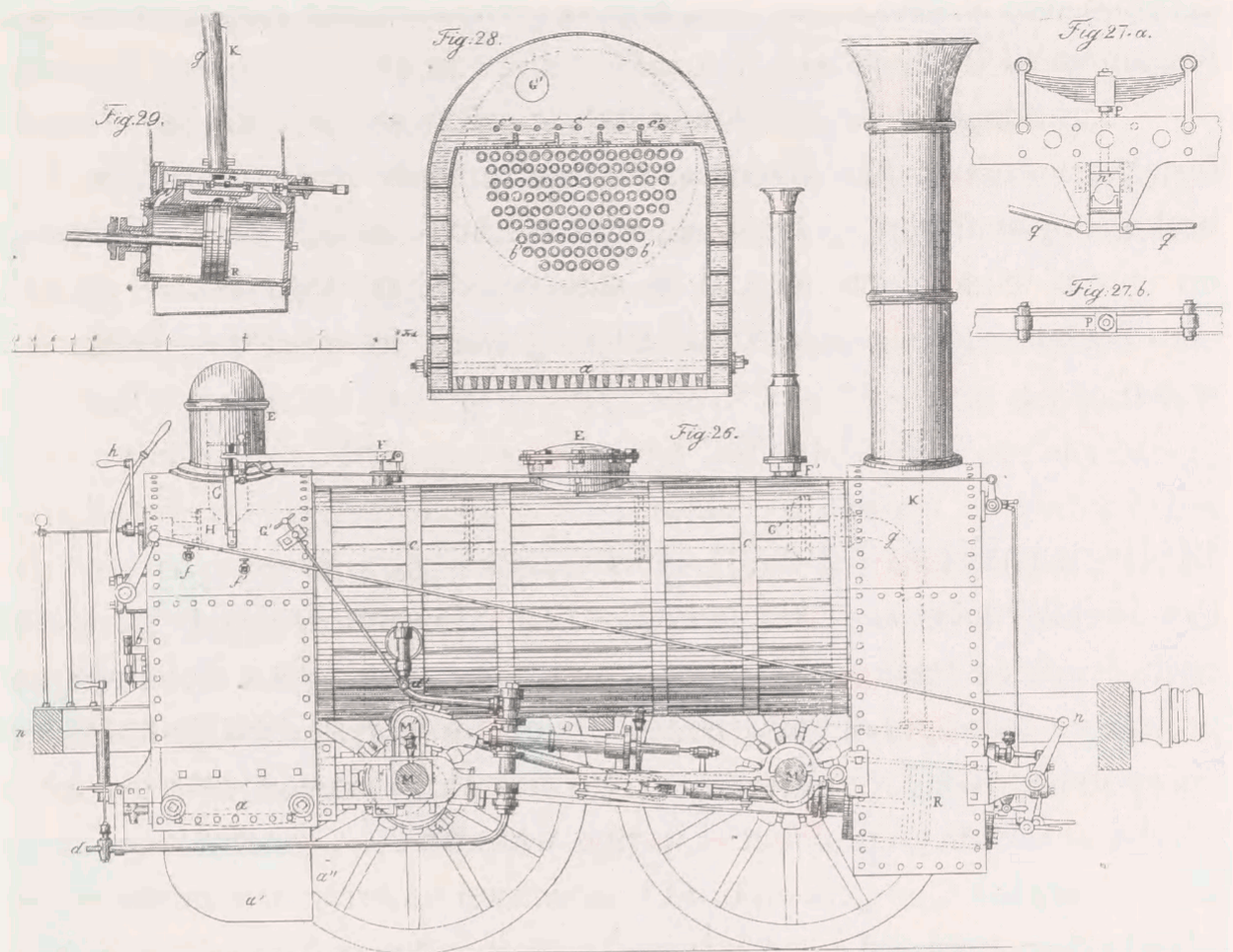

I1839 trykte G.F. Ursin sin forelæsningsrækkeom dampmaskinen i sit tidsskrift Nyt Magazin for Kunstnere og Haandværkere bd. 3, og naturligvis måtte han også præsentere Robert Stephensons dampvogn Raketten, som ses her.

forløbet som detaljerede tegninger af de tre deltagende lokomotiver. Et andet eksempel er tre artikler om "Daguerre's Opfindelse til at frembringe photogeniske Billeder", som blev bragt i august 1839, kort efter hans egen offentliggørelse af opfindelsen. I oktober og november bragte Magazinet så Daguerre's egen opskrift og beskrivelse af fremgangsmåden ved processen over tre numre.

Formidlingen af teknologi i form af bøger, magaziner og tidsskrifter rettede sig dog i vigende grad mod håndværkere og kunstnere. Den videnskabelige teknologi begyndte at dominere over håndværkets teknik, det skulle Ursin allerede sande i trediverne. Han måtte i 1835 indstille udgivelsen af magazinet angiveligt på grund af økonomiske problemer. I stedet kastede han sig over arbejdet med at oversætte Forelæsninger over Naturlæren af Heinrich Wilhelm Brandes i fire bind, som var en populær indføring i naturvidenskaben, beregnet til undervisningsbrug. Magazinet blev dog 
genoplivet to år senere som Nyt Magazin for Kunstnere og Haandværkere, der udkom indtil 1842.

Samtidig med Ursin virkede Ole Jørgen Rawert gennem et omfattende forfatterskab, hvor han blandt andet beskæftigede sig indgående med at beskrive og analysere landets industrielle forhold. Rawert var ikke primært optaget af teknologien, men af de statsøkonomiske forhold. Her så han teknologien som et brugbart middel til at skabe fremskridt og velstand i staten.

\section{Mellem militær og civil Teknologi}

Der foregik i løbet af 1800-tallet en omfattende sammenblanding mellem civil og militær teknologisk udvikling. Militæringeniørerne blev anset for praktikere, mens polyteknikerne blev regnet for teoretikere. Oprettelsen af den polytekniske Læreanstalt i 1829 betød en tiltagende videnskabeliggørelse af teknologien i løbet af forrige århundrede. Gennem det teknisknaturvidenskabelige gennembrud i industrien omkring århundredskiftet, sikrede de polytekniske kandidater sig efterhånden en central rolle i samfundsudviklingen.

Flere polyteknikere underviste dog samtidig på Læreanstalten og Den militære Højskole. Både professor Johan Arndt Dyssel og hans efterfølger J.F.C.E. Wilkens underviste i maskinlæren begge steder. Det skete på grundlag af den konkret beskrivende metode fremfor gennem den matematisk abstrakte mekanik. Dyssel udgav allerede i 1830 Læren om Haandværksredskaber og Haandværkstøi, mens hans senere forelæsninger i maskinlæren i fyrrerne kom i flere bind til internt brug på Den militære Højskole, altså uden for offentlighedens rækkevidde. Wilkens oversatte omkring 1840 Karl Karmarschs Lærebog i Metallernes mechaniske Technologie, som han dog først udgav i en stærkt bearbejdet udgave i 1852. De polytekniske lærebøger antog et stadig mere matematisk abstrakt og specialiseret udtryk.

I 1885 udsendte Kaptajn i Artilleriet Frederik Wagner Lærebog i Teknologi, der var tænkt som en afløser til Karmarsch. Bogen var beregnet til undervisningen ved hærens Officersskole på Frederiksberg Slot, men udkom samtidig med civil anvendelse for øje. Værket var en generel mekanisk teknologi, der afhandlede teknikken i almenhed uden at skele til bestemte 
formål. Den encyclopædiske metode bestod i en perfektionering af de konkrete beskrivelser af teknikken. Hvad der er bemærkelsesværdigt i denne forbindelse, var forfatterens definition af begrebet teknologi:

"Teknologien er Læren om Naturprodukternes Omdannelse til Brugsgjenstande, dens Forhold til Industrien kan sammenlignes med Grammatikkens Forhold til Sproget." (Indledning)

Polyteknikken havde altså på dette tidspunkt over et århundrede fået udviklet et systematisk sprog, der byggede på beskrivelser af den industrielle udvikling. Sproget var præget af det didaktiske krav om eksakthed, entydighed og overførbarheden fra forfatter til læser. Der findes ingen fanfare for fremskridtet i en sådan teknologi. Her er kun sagligheden til stede, den rene tekniske prosa som præsenterer teknologien til internt brug af fagfolk. Med et eget sprog lever denne litterære fortælling videre i det tyvende århundrede. Den findes som genre i rendyrket form af brugsanvisninger, gør-det-selv bøger, instruktionsbøger, ståbier og manualer til konkrete produkter.

\section{Ingeniøren synger med på fremskridtets melodi}

I 1870erne begyndte de polytekniske kandidater at udvikle en identitet som egentligt dannede og dermed kulturbærende stand i kraft af deres polytekniske videnskab. Derved kommer polyteknikerne til at virke aktivt i besyngelsen af fremskridtet. Selvbevidstheden blandt polyteknikerne var voksende, de begyndte at repræsentere fremskridtet i sig selv. Det kom til udtryk i det glade studenterliv omkring Polyteknisk Forening, og det fandt afløb i opførelsen af adskillige operaer, operetter og revyer. Blandt andet opførte polyteknikerne operetten Den skønne Magdalene med Henrik Pontoppidan i hovedrollen. Splittelsen mellem teknik og kultur er tydelig hos Henrik Pontoppidan, som indstillede sit polytekniske studium kort før afgangseksamen og i stedet valgte en livsbane som forfatter. Hovedpersonen i hans gennembrudsroman 'Lykke - Per', (1898 - 1904), er polytekniker og får sit virke som ingeniør. Pontoppidan forlenede her det moderne gennembruds primære skikkelse med en kulturel fernis og identitet. Myten om polyteknikken som fremskridtets bannerfører blev bygget op i litteraturen i disse år. Johs. V. Jensen besang fremskridtets storhed i Den gotiske Renaissance 


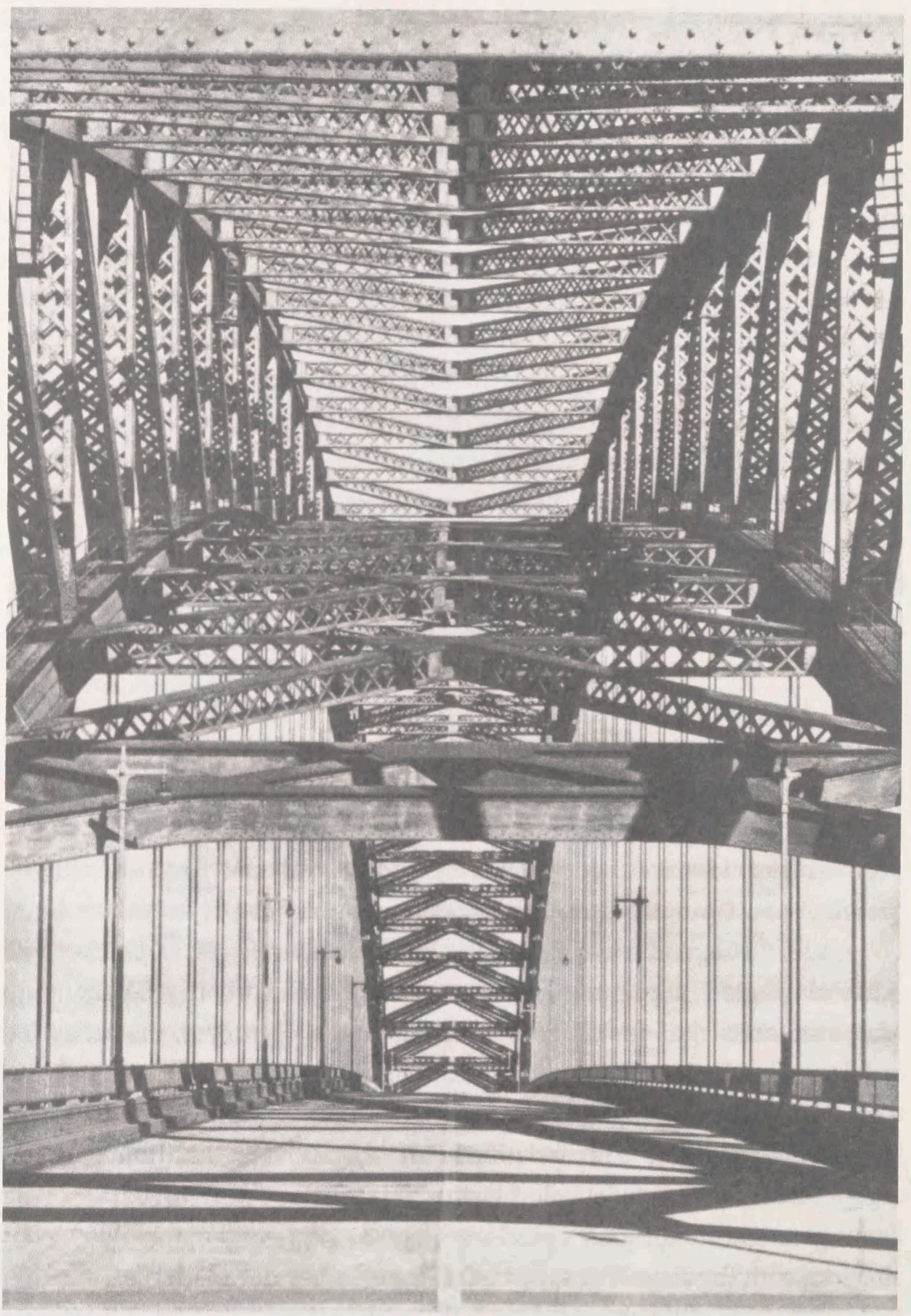

Foto af Kill van Kull-broen fra bogen Teknikkens vidundere i fartens tidsalder af Edgar B. Schieldrop (dansk udg. 1953), som godt illustrerer, hvordan teknik og ingeniørarbejde er blevet præsenteret som fascination. 
fra 1901, som delvist er en fascineret reportage fra Verdensudstillingen i Paris i 1901, der også havde Eiffel-tårnet som vartegn.

Fascinationen af det teknologiske fremskridt trænger ind i drenge og ungdoms-litteraturen efter århundredskiftet. Karakteristisk er tyskeren Bernhard Kellermanns ingeniørroman Tunellen fra 1912, som kom i dansk oversættelse året efter og blev genudgivet som Tranebog i midten af tresserne. En fortættet spændingsroman om det umulige projekt at grave en tunnel mellem den nye og den gamle verden. Efter talrige tilbageslag lykkes kampen mod naturkræfterne med enorme tab, fordi den ledende ingeniør er den stædigste. I tusindvis af arbejdere omkommer undervejs, ligesom ingeniøren selv må ofre kone og barn på fremskridtets alter for at kunne gennemføre linien fra kyststation til kyststation. En kulørt drengeroman. Men immervæk noget der kunne anspore drengesindet og give læselyst til de mere seriøst anlagte teknikhistorier, ingeniør- og opfinderbiografier, som blandt andre Helge Holst, Poul la Cour og Povl Vinding var forfattere af.

De nyttige bøger handler om det teknologiske fremskridt. De forskellige litterære genrer, fra den polytekniske fortælling til den tekniske sagprosa, er opfindernes frontberetninger fra den moderne samfundsudvikling. Præsentationer og repræsentationer, der henter deres stof i teknikkens stadige forvandling og udbredelse i samfundet. Uden ny teknik ingen ny fortælling. På den måde er det blevet fortællingen om samfundets tekniske fremskridt, der skaber selve grundlaget for at forstå et fænomen som teknisk forandring.

\section{Menneskeaandens Sejre}

I 1904 udgav bibliotekar Helge Holst i et samarbejde med højskolelærer på Askov, Poul la Cour, en populær bog, der handlede om det tekniske fremskridt. Det var en polytekniki ordets bedste forstand, da den afhandlede alle former for teknik. Bogen tog afsæt i nu'et, hvor den beskrev teknikkens funktionsmåde - the state of art. Hertil blev der lagt en historisk berettende dimension, som forklarede teknikkens naturvidenskabelige forudsætninger og revolutionerende betydning. Med den kraftfulde og lidt højstemte titel, Menneskeaandens Sejre, signalerede forfatterne både tidsånden omkring århundredskiftet og talte direkte til ungdommens begejstring og fantasi. Med 
undertitlen, Opfindelsernes Historie i Omrids, blev læseren sporet direkte ind på teknikkens centrale betydning for udviklingen af historien. Med forfatternes egne ord i Indledningen gjaldt det om, at fæstne "Blikket paa de Vanskeligheder og Hindringer, der har været at overvinde, og paa de Opfindelser, gennem hvilke Sejren er vundet".

\section{De postmoderne fortællinger om fremskridtet}

Efter første verdenskrig har udviklingen spoleret forehavendet at beskrive teknikken grundigt, fuldstændigt og med almen nytte for øje. Det lader sig ikke gøre at orientere bredt og dækkende om teknikkens funktion og fremskridt. Den nyeste udgave af Helge Holst's Opfindelsernes Bog fra 1924 er slutstenen. Selv "under medvirken fra adskillige Fagmænd ", som det stadig hed på titelbladet af de fire tykke bind, måtte ambitionen demonteres. Præsentationen af teknikkens funktion og repræsentationen gennem fortællingen om fremskridtet var endegyldigt blevet adskilt af udviklingen selv i form af den videnskabelige arbejdsdeling. Den polytekniske fortælling er offer for den specialisering, som teknologien har udvirket. Lærebøgerne er blevet monografier og gennem det matematiserede udtryk, er de blevet ulæselige for lægmand. De nyttige bøger henvender sig nu til specialisten med den snævre horisont. De er altså ikke længere polytekniske.

Den polytekniske tradition er næsten ophørt som genre efter 2. verdenskrig. Nu og da forsøger litteraturen et come back, som regel med en begrænset fortælling til et enkelt bind, som Umberto Eco's og G.B. Zorzoli's Opfindelsernes Historie. Fra stenalderen til de kunstige satelitter, et lærd populærværk fra 1962. En polyteknisk fortælling med danske forfattere Skruen uden ende har set dagens lys så sent som i 1990. Fremskridtet har gjort den polytekniske fortælling til en historisk anakronisme.

Ambitionen at sætte hele verden på udstilling er opgivet. Hvad er nytten af polyteknikken, når ingen fornuftige mennesker længere tror på, at fremskridtet er styret af en højere fornuft. Udviklingen kan derfor dårligt forudses eller forudsiges. At styre den er blevet helt umuligt. Teknologiens fremskridt er blevet for mangfoldige, uforudsigelige og katastrofale til at kunne rummes i én stor historie. Der må stadigt flere historier til for at kunne præsentere de tekniske spørgsmål på dækkende måde. Industriens Tænke- 
tanke og offentlighedens ekspert-grupper producerer i dag betænkninger som svar og modsvar på alt muligt. Det vigtige spørgsmål er forlængst druknet i mængden af ligegyldige svar.

Repræsentationen af teknologien som et fremskridt strømmer i dag fra uventede kilder. Fremskridtsoptimismen som ideologisk konstruktion er brudt sammen efter den 2. verdenskrig. Fortællingen om fremskridtet er degenereret til ren fascinationshistorie, gerne skåret over læsten først og størst, højest, hurtigst og mest mageløs. I den populære offentlighed antager teknologiens fascinationsformer en nærmest uanstændig, pornografisk karakter. Fokuseringen sker udelukkende på selve akten, mennesket fremstår som staffage, påskud og pynt. Afbildningerne ses i de mest forskruede positurer og halsbrækkende stillinger, som kameraet indtager i voyeristisk øjemed. Den glittede og farvestrålende æstetik i magasinerne med Alt om både, -biler, -Hi Fi og -computere, præsenterer sig som var det Week-End Sex og Rapport. Illustreret Videnskab og Cupido ligger fint sammen på disken i kiosken.

Fascinationen af teknologien pakkes nu om stunder ind i elektronikkens vidunderlige verden. PH's Danmarksfilm om fremskridtet vakte anstød, da den kom frem i trediverne. I dag virker den temmelig harmløs. Der sker en tilpasning til det moderne i efterkrigstidens danskelystspil. Morten Korch og Dirch Passer-film beskriver opbruddet fra de traditionelle livsformer, set gennem fremskridtets tilsynekomst på arenaen. TV-alderen bringer udviklingen ind i dagligstuen. Poul Hammerich's store Danmarkskrønike på fjernsyn fortæller frivilligt og ufrivilligt, hvordan moderniseringen er skredet frem i efterkrigstiden. Teknologien er blevet indfældet i fortællingen.

Hvad er nytten af de nyttige bøger, når diverse computerspil forhandles både over og under disken. Nyttige bøger skal virke opdragende. Elektronikkens fantastiske univers er en leg, som troligt lover, at det er bedre her end i den virkelige verden. Ja, at dette faktisk nærmest er den virkelige verden, blot man følger brugsanvisningen. På denne måde skaber teknologien til stadighed sin egen fortælling og danner sin egen offentlighed i takt med samfundets modernisering. Teknologien stiller bestandigt sine fremskridt ud til beskuelse.

Eco, Umberto, Zorzoli, G.B.: Opfindelsernes Historie. fra stenalderen til de kunstige satelitter, 1962.
Nielsen, K., Nielsen, H., Siggaard Jensen, H.: Skruen uden ende, 1990. 